\title{
ADDITÍV GYÁRTÁS HUZALELEKTRÓDÁS VÉDŐGÁZOS ÍVHEGESZTÉSSEL
}

\section{ADDITIVE MANUFACTURING BY GMAW}

\author{
Uzonyi Sándor $^{1}$, Asztalos Lilla ${ }^{2}$, Dobránszky János ${ }^{3}$ \\ 1, 2 BME Gépészmérnöki Kar, Anyagtudomány és Technológia Tanszék \\ Magyarország, 1111 Budapest, Müegyetem rkp. 3. telefon: +3670 2487278 \\ ${ }^{3}$ MTA-BME Kompozittechnológiai Kutatócsoport \\ Magyarország, 1111 Budapest, Müegyetem rakpart 3. telefonszám: +3614631934 \\ ${ }^{1}$ uzonyi.sandor90@gmail.com, \\ 2 asztalos.lilla92@gmail.com, \\ 3 Dobranszky.Janos@eik.bme.hu
}

\begin{abstract}
Additive manufacturing (AM) as a rethinking of build-up welding, growing use itself in several fields of mechanical engineering. Using AM, optional geometry can be build, which is limited by the volumetric resolution of the applied process. In industrial application, laser-based AM processes are most popular with integrated five-axis machining centers. The use of metal active gas welding for AM is less honed but perfectly suitable for robotisation. The application of AM can produce spectacular results in the world of arts (,printed" bridges), but its technical use has many challenges. The background of the research is a need that came up at an industrial partner of Flexman Robotics Ltd. Compared to the traditional build-up welding, the robotized MAG-AM can assure a clear cost-effectiveness when repair large forging tools; because of much less welding consumable consumption and posterior fashioning, thanks to very precise following of the tool geometry during the welding process.
\end{abstract}

Keywords: welding, robotic welding, surfacing, additive manufacturing, GMAW.

\section{Összefoglalás}

Az angolul additive manufacturing (rövidítve $\mathrm{AM}$ ) néven ismert eljárások egy része nem más, mint a hagyományos felrakóhegesztés újragondolása, és egyre nagyobb teret hódít magának a gépipar több ágazatában. Alkalmazásával tetszőleges geometria felépíthető, amelynek „csak” az alkalmazott hegesztési eljárás térfogati felbontása szab határt. Ipari alkalmazásban elterjedt a lézersugaras, poradagolásos eljárás, amit öttengelyes megmunkáló központokba integrálnak. A védőgázos, huzalelektródás ívhegesztés alkalmazása az additív gyártásra kevésbé kiforrott, de robotosítva hasonlóan alkalmas. A koncepció alkalmazása látványos eredményeket produkál a müvészet világában (müvészeti tárgyak, „,nyomtatott” hidak), viszont termelési célú müszaki alkalmazása még számos kihívást rejt. A kísérletek hátterében áll a Flexman Robotics Kft. ipari partnereinél felmerült fejlesztési igény. Ezzel az eljárással kívánjuk költséghatékonyabbá tenni kovácsszerszámok javító-felrakó hegesztését, a kisebb hegesztőanyag felhasználás és utólagos megmunkálási igény által.

Kulcsszavak: hegesztés, robotositott hegesztés, felrakóhegesztés, additív gyártás, MAG hegesztés. 


\section{Az additív gyártás bemutatása}

Additívnak nevezzük az olyan gyártási eljárásokat, amelyek során nem egy, a véglegesnél nagyobb méretü elögyártmányból vagy alapanyagból kiindulva anyagleválasztás során jutunk el a végleges geometriához, hanem a végleges geometriánál kisebb előgyártmányra, alapanyagra viszünk fel, adunk hozzá rétegről rétegre anyagot. Ilyen vagy ehhez hasonló gyártási technológiákat már régóta használnak fémiparban jellemzően felületmódosításra vagy javításra, ezt felrakóhegesztésként ismerjük. Az utóbbi években egyre inkább elterjedő fémporszinterelés is e megmunkálások családjába tartozik; ekkor lézer- vagy elektronsugarat használnak ,szerszámként”. Ezt a folyamatot azokban az esetekben, amikor az anyaghozzáadást nem felületek módosítására használjuk, hanem geometria építésére, „3D-nyomtatás”-nak illetve ,gyors prototípusgyártás"-nak nevezték régebben. A gyors prototípusgyártáson ez a technológia már túlhaladt, teljesen funkcionáló, egyedi készítésü szerszámok készülnek ilyen módon. A 3D-nyomtatás véleményünk szerint nem megfelelő kifejezés, különösen fémek feldolgozása esetén [1].

\subsection{Az additív gyártás helyzete az iparban}

Az additív gyártás megítélése vegyes. A General Electric több mint százezer, ilyen technikával készült alkatrészt tervez beépíteni a LEAP és GE9X turbináiba 2020-ig, míg a Foxconn igazgatója ,vásári mutatványnak" tartja ezt a gyártástechnológiát, nem lát benne potenciált. Azokon a területeken, ahol a kis sorozatszámban készülő termékek egy drága öntő-, kovács- vagy fröccsöntőszerszámot nem vagy csak nehezen termelnek ki, érdemes megfontolni az $\mathrm{AM}$ bevezetését (1. ábra). Ilyen terület lehet pl. a harcirepülögép-gyártás, vagy az autóipar luxus és egyedi gépjármúvekre specializálódott ágazatai $[1,3]$.

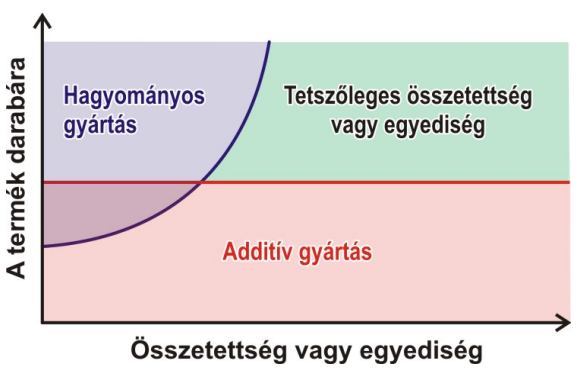

1. ábra. Az additív gyártás „felségterülete” a termékek komplexitása és ára térképén

\subsection{Az additív gyártás megítélése}

Fontos, hogy a mérnöktársadalom ne ragadtassa el magát túlságosan, és a szenzációhajhászás, mérnöki rekorddöntés kísérletek helyett helyén kezelje az additív gyártást. Ebben a napi sajtó és média nincs segítségünkre, mivel folyamatosan mindenre alkalmas csodatechnológiaként mutatják be, ez által sokszor nem csak a laikusok számára alakul ki torz kép az additív gyártással kapcsolatban.

\subsection{Fémtermékek additív gyártása}

A fémtermékek additív gyártására szolgáló eljárásokat két fő csoportba oszthatjuk. Az egyik a por, a másik a tömör (huzal vagy szalag) alapanyagú. A port használó eljárások közül felületi tulajdonságok módosítására, felrakóhegesztésként már régóta használatos a poradagolásos plazmaív- és lézersugaras hegesztés is. Tömör alapanyagot használó gyártási eljárásnak tekinthető a klasszikus felrakóhegesztés is, végezzük azt bármilyen eljárással. Felrakóhegesztést végeznek a célból, hogy a kopott éleket, felületeket pótolják, újraépítsék. Innen már csak egy lépés annak megfontolása, hogy az egész alakot ilyen módon építsük fel. Erre nem alkalmas akármelyik hegesztési eljárás az elöbb felsoroltak közül. Ilyen célra a volfrámelektródás védőgázos ívhegesztés és a huzalelektródás ívhegesztés a legalkalmasabb, ezeket a nemzetközi szakirodalomban WAAM névre keresztelték: „wire and arc additive manufacturing" [1-2, 4-5]. 


\subsection{Additív gyártás huzalelektródás védőgázos ívhegesztéssel}

Ha huzalelektródás védőgázos ívhegesztéssel szeretnénk felépíteni egy terméket, alaposan meg kell ismerni a hegesztés technológiai változóinak az ömledékre és a kialakult varratgeometriára gyakorolt hatásait, hogy megfelelő hegesztési pályát generálhassunk. Az, hogy a termék rétegeit alkotó hegesztett sorokat milyen séma szerint tervezzük meg, alapvetően meghatározza a termék minőségét és a gyártási sebességet. A pályagenerálás többnyire számítógéppel történik. A gép a gyártani kívánt termék 3D modelljét adott irányban, adott távolságokban rétegekre bontja, majd a rétegek feltöltéséhez egy elöre meghatározott séma szerint pályát generál.

\subsection{Pályagenerálás}

A pályagenerálási logikától függetlenül fontos meghatározni, hogy milyen átfedése legyen a varratsoroknak, hogy egyenletes magasságú réteget kapjunk. Sok különböző pályagenerálási logika létezik, ezek közül a legfontosabb számunkra, ebben a tanulmányban, a kontúr, a cikcakk és a hibrid.

A pályageneráló szoftverek többsége erre a feladatra átalakított, egyébként $\mathrm{CNC}$ megmunkálóközpontokhoz használatos program. A szakirodalomban a legtöbbször mint 2,5D feladatot kezelik a problémát, ahol két vízszintes tengely végez szinkronmozgást, és egy ezekre merőleges, külön vezérelt tengellyel állítjuk be a rétegek közötti magasságot.

Vékony falú termékek esetén a kontúr pályát részesítik előnyben (2. ábra), ugyanakkor fontos tudni, hogy a kontúr pályás építés során a termék belsejében gyakran maradnak üregek, ahol a sorokat nem sikerül teljesen összeolvasztani. Tehát nem garantálható a teljes tömörség. A jól megválasztott átfedés a hegesztési sorok között segíthet ezen a problémán [9].

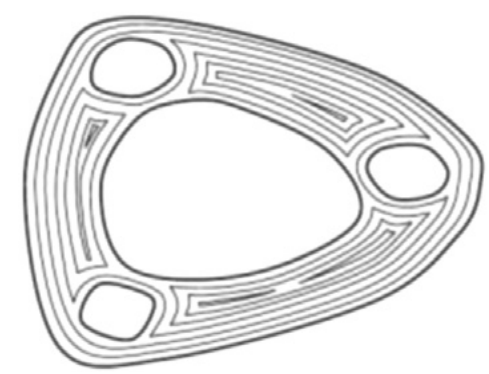

2. ábra. A kontúr pályakövetés tervezési sémája

\section{Hegesztési kísérletek}

A hegesztési kísérleteink során először felmértük a lehetőségeinket és a korlátainkat a laboratóriumban található hegesztőrobot cellával. A YASKAWA EA1400 hattengelyes hegesztőrobot igen nagy mozgásszabadságot biztosít. A pályageneráláshoz nem állt rendelkezésünkre program, azt a hagyományos kézi betanítással végeztük. A robotra szerelt SKS áramforrás megfelelő technikai színvonalat képvisel, széles áramerősség tartományban képes dolgozni. A gázhütéses hegesztőpisztoly szabja meg a maximálisan használható áramerősséget, illetve annak idejét. A hegesztőcella additív gyártásra való alkalmasságának felméréséhez, $100 \mathrm{~mm}$ magas, $25 \mathrm{~mm}$ széles és 150 $\mathrm{mm}$ hosszú „téglatestet” építettünk fel egy $25 \mathrm{~mm}$ vastag alaplemezre. Ehhez 1,0 mm átmérőjü, EMK8 (G4Si1) huzalt és $82 \% \mathrm{Ar}$, $18 \% \mathrm{CO}_{2}$ védőgázkeveréket használtunk.

\subsection{Próbahegesztések}

A próbahegesztéseket $3 \mathrm{~mm}$ vastag S235JR anyagú acéllemezeken végeztük. Mivel a távlati cél szerszámacélok hegesztése, amelyek előmelegítése legalább 300$500{ }^{\circ} \mathrm{C}$, a próbahegesztések során fokozatosan haladtunk $300{ }^{\circ} \mathrm{C}$ sorközi hőmérsékletig, és többféle pályaépítési logikát is kipróbáltunk. Cikcakk pálya esetén néhány réteg után a harmadik sor annyira túlhevült, hogy teljesen lefolyt. Különösen igaz ez, ha minden réteg ugyanonnan indul, és ugyano- 
da érkezik, a függőleges pisztolytartási kényszer tovább nehezítette a helyzetet.

Gyakorlati úton is megbizonyosodhattunk róla, hogy a 2,5D megközelítés helytelen. Rövidzárlatos anyagátviteli mód helyett impulzusos, szabályozott cseppleválasztással is próbálkoztunk, a rétegek orientációját is cserélgettük. Sajnos a szabályozott cseppleválasztáshoz alkalmazott nagy áramlökések nem tesznek jót a hegfürdő mozgásának. Ha oldalról nem támasztja semmi a fürdőt, fröcskölésnek már nem is nevezhetően szórja ki ilyenkor az anyagot az ív az alaplemezre, annak ellenére, hogy a pisztolyt „rátartottuk” a varratra.

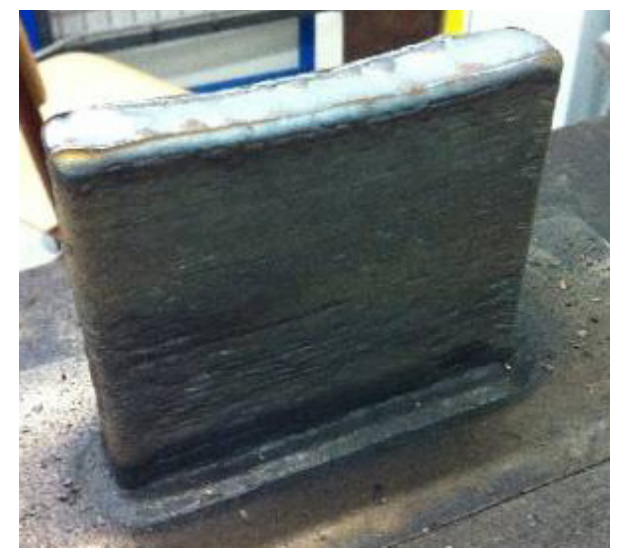

3. ábra. Az elkészült monolit tömb

E tapasztalatok alapján újragondoltuk a 2,5D pályagenerálást és egy továbbfejlesztett hibrid pályát hoztunk létre, ahol a rövid ívvel készülő kontúrt egy nagy áramú lengetett sor tölti fel. Ilyen módon hegesztettük az előző fejezet végén leírt próbatestet (3. ábra), 37 rétegben 114 sorral, 8 óra alatt.

\section{Vizsgálatok}

Az elkészült monolit szerkezetet optikai mikroszkóppal a vizsgáltuk, valamint három szakító próbatestet is kimunkáltunk. A felrakott anyag ferrites, finomszemcsés, hegesztett kötések ömledékére jellemző szer- kezet. Egyenletes, véletlenszerü elrendezkedésü, néhánytól néhány tíz $\mu \mathrm{m}$ terjedő átmérőjü salakzárványokkal terhelt, ezek a kontúr és a töltő sorok határán helyenként sorba rendeződnek. Helyenként néhány $\mu \mathrm{m}$ es gázpórusok is megfigyelhetőek. A mechanikai vizsgálatok alapján a monolit tömb és a huzal varratának lágyított állapotban jellemző mechanikai tulajdonságai egyformák. Az alkalmazott eljárás felbontóképessége hozzávetőlegesen $1 \mathrm{~mm}$, a felhegesztett anyagnak kb. 90\%-a hasznosítható.

\section{Következtetések}

Kísérleteink alapján kijelenthető, hogy a huzalelektródás védőgázos ívhegesztéssel történő felrakó hegesztés additív gyártásra kiválóan alkalmas. Az általunk használt pályagenerálási logika az eddigieknél gyorsabb és megbízhatóbb. A 2,5D szemlélet helyett hegesztéstechnológiai szempontokat helyezve elötérbe a problémák egészen más megvilágításba kerülnek.

\section{Szakirodalmi hivatkozások}

[1] Conner BP et al.: Making sense of 3-D printing: creating a map of additive manufacturing. Additive Manufacturing, 1-4 (2014) 64-76.

[2] Silva RJ, Barbosa GF, Carvalho J: Additive Manufacturing of Metal Parts by Welding. IFAC-PapersOnLine 01/2015; 48(3):23182322.

[3] Rockstroh T, Abbott D, Hix K, Mook J: Additive manufacturing at GE Aviation. Industrial Laser solutions for manufacturing, 26 (2013) 6.

[4] Ding D, Pan Z, Cuiuri D, Li H: A multi-bead overlapping model for robotic wire and arc additive manufacturing. Robotics and Computer-Integrated Manufacturing, 31 (2015) 101-110.

[5] Murr LE, Martinez E, Amato KN, Gaytan SM, Hernandez J, Ramirez DA, Shindo PW, Medina F, Wicker RB: Fabrication of Metal and Alloy Components by Additive Manufacturing: Examples of 3D Materials Science. Journal of Materials Research and Technology, 1 (2012:1) 42-54. 